\title{
Sebastian Piotrowski
}

Instytut Filologii Romańskie;, KUL

\section{JAK BADAĆ AKWIZYCJĘ JEZZYKA OBCEGO W KLASIE, CZYLI O ZADANIU W PERSPEKTYWIE BADAŃ ILOŚCIOWYCH I JAKOŚCIOWYCH}

\section{How to investigate language acquisition in the classroom? Quantitative and qualitative perspectives on language task}

\begin{abstract}
In studies on second language acquisition in formal settings, techniques characteristic of both qualitative and quantitative research paradigms are applied. In the first part of the article, we present general reflection on the methodology of studies on second language acquisition, with a particular emphasis on the role of exploratory research in the analysis of the process of second language teaching/learning in formal settings. In the second part, we present the concept of task, stressing its usefulness as a basic unit of analysis of the corpus of linguistic data obtained in the classroom.
\end{abstract}

\section{Wstęp}

Badanie procesu nauczania/uczenia się języka obcego (JO) w warunkach formalnych wymaga wglądu w to, czym zajmują się uczestnicy komunikacji w klasie. Allwright (1983) definiując podejście typu classroom-centered research (badania nad akwizycja JO w klasie) stawia sobie za cel badanie tego, co się dzieje w klasie, gdy wchodza do niej nauczyciel i uczniowie (ang. what happens inside the classroom when learners and teachers come together). Ten prosty z pozoru cel stawia jednak przed badaczem poważne wyzwania natury metodologicznej dotyczące zebrania korpusu danych i ich analizy. Poniżej proponujemy refleksje na temat metodologii badań nad akwizycją JO i roli, jaką może spełnić w niej zadanie jako jednostka analizy korpusu danych zebranych in vivo w klasie. W pierwszej części nakreślamy krótką charakterystykę dwóch ogólnych typów badań nad akwizycją JO (badania ilościo- 
we i jakościowe), w drugiej zaś przykład badania jednostkowego (badanie eksploracyjne) pod katem jego metodologicznych implikacji.

\section{Badania ilościowe a badania jakościowe}

Terminy badanie ilościowe i badanie jakościowe określają dwa różne sposoby prowadzenia badań. Według rozróżnienia Reichardta i Cooka (1979), badanie ilościowe ma charakter inwazyjny, kontrolowany, obiektywny i jest zorientowane na określony rezultat, z kolei badanie jakościowe ma charakter naturalny, niekontrolowany, subiektywny i jest zorientowane na obserwacje procesu. Ellis (1990) nazywa badania ilościowe badaniami polegającymi na testowaniu hipotez. (ang. bypothesis-testing research), zaś badania jakościowe nazywa badaniami eksploracyjnymi (ang. exploratoryinterpretative research). Obie metodologie badań moga być traktowane bądź w sposób dychotomiczny (Reichardt i Cook 1979) bądź komplementarny (LarsenFreeman i Long 1991). Raz więc podkreśla się konieczność wyraźnego wyboru między jednym a drugim paradygmatem, innym razem dopuszcza się, czy wręcz zachęca, do stosowania w ramach jednego badania różnych technik, zarówno o charakterze jakościowym, jak i ilościowym. Oba stanowiska sa odbiciem odmiennych strategii podejścia do samych badań, choć wydaje się, że całkowita rozdzielność badań ilościowych i jakościowych jest bardziej postulatem teoretycznym niż rzeczywistością. Jak słusznie zauważają Larsen-Freeman i Long (1991), badanie jakościowe i ilościowe należy traktować jako bieguny pewnego continuum, na którym sytuuje się cała seria technik, od czysto jakościowych (introspekcja), poprzez techniki pośrednie (obserwacja), po czysto ilościowe (ekesperyment sensu stricte). Granice pomiędzy poszczególnymi technikami nie są tak ostre jak mogłoby się wydawać, z kolei wyboru tej najbardziej adekwatnej nie można dokonywać w oderwaniu od dziedziny, przedmiotu i celu badania.

W literaturze dotyczącej akwizycji języka obcego odnajdziemy przykłady zarówno badań par excellence ilościowych/jakościowych, jak i takich, w których zastosowano kombinację technik pochodzących z obu metodologii. Na gruncie europejskim, badania podłużno-transwersalne w ramach wieloletniego Projektu ESF (European Science Foundation) nad akwizycją języków obcych w warunkach naturalnych (Perdue 1982) sa przykładem zastosowania takiej właśnie podwójnej metodologii. Z jednej strony korzystano z technik jakościowych (introspekcja, obserwacja), z drugiej strony, istnienie grupy kontrolnej (rodzimi użytkownicy języka, który był zarazem językiem docelowym dla uczących się go), rygorystyczne wykonywanie tych samych zadań przez wszystkich badanych (emigranci uczący się języka kraju, do którego przybyli), a także postawienie wyraźnej hipotezy badawczej (tutaj: czy istnieja uniwersalne formy i struktury w przypadku podstawowej odmiany interjęzyka - nazwanej później przez Kleina i Perdue (1997) basic variety - bez względu na język wyjściowy i docelowy) wskazują na eksperyment.

Ze względu na specyficzność samego przedmiotu badań, jakim jest akwizycja języka, i dużą ilość zmiennych, nadal dużą rolę pełnią tutaj techniki eksplo- 
racyjne, a sama dziedzina akwizycji JO szeroko czerpie z dyscyplin, które na tych właśnie technikach są oparte, jak etnografia komunikacji (Hymes 1966) czy też etnometodologia (Gülich 1991). W badaniach nad językiem i komunikacją badania jakościowe, takie jak systematyczna obserwacja, przygotowują często grunt pod badania ilościowe. Innymi słowy, eksploracja pomaga w określeniu relewantnych dla badań kategorii (np. typów pytań, zadań) i postawieniu hipotez, które moga być następnie testowane na drodze eksperymentalnej.

\section{Badania ilościowe i jakościowe nad akwizycją JO w klasie}

Według Chaudrona (1986), w badaniach nad akwizycja JO w warunkach instytucjonalnych, niezależnie od metodologicznej orientacji, chodzi zawsze o dwie podstawowe kwestie: 1) ustalenie, jakie elementy procesu nauczania w klasie maja najskuteczniejszy wpływ na wyniki uczenia się oraz 2) odkrycie, dlaczego owe relacje istnieja. Z jednej strony odnajdziemy tu badania ilościowe, zorientowane na produkt, mające na celu na przykład ustalenie, jaki typ pytań jest bardziej skuteczny dla procesu uczenia się JO, a z drugiej strony badania jakościowe, zorientowane na proces, których głównym celem jest np. zidentyfikowanie i opisanie typów zadań czy też strategii komunikacyjnych pojawiających się u interlokutorów w klasie.

Do grupy badań ilościowych można na przykład zaliczyć badania nad wpływem typu zadania na uczestnictwo w interakcji (Doughty i Pica 1985, 1986). W ramach eksperymentu, autorki zbadały, jak na ilość i jakość interakcji wpływają zadania, w których wymiana informacji pomiędzy uczestnikami jest albo obowiązkowa, albo opcjonalna (one-way information gap task vs. two-way information gap task). Podobne badania przeprowadził też Nunan (1991), który zbadał wpływ na interakcję zadań otwartych, tj. takich, w których istnieje więcej niż jedna poprawna odpowiedź i zadań zamkniętych, w których istnieje jedna poprawna odpowiedź lub ograniczona ilość poprawnych odpowiedzi (open tasks vs. closed tasks). Z kolei Fotos i Ellis (1991) w swoich badaniach nad uczeniem gramatyki oraz rozwijaniem wiedzy eksplicytnej i kompetencji komunikacyjnej u uczących się porównywali skuteczność zadania gramatycznego z jednej strony (uczący się mieli formułować reguły po przedstawieniu im jednostek gramatycznych i niegramatycznych) i tradycyjnej lekcji gramatyki z drugiej (uczniowie wysłuchali wyjaśnień gramatycznych, które uczący podał explicite).

Do grupy badań jakościowych można zaliczyć badania Germaina (1999), który na podstawie szerokiego korpusu danych zebranych w szkołach badał strukturę lekcji JO i typy czynności ${ }^{1}$. Owocem tych badań eksploracyjnych jest funkcjonalna typologia czynności dydaktycznych (fr. activités didactiques) oraz model

\footnotetext{
1 W badaniach Germaina (1999) nad nauczaniem/uczeniem się JO przedmiotem analiz jest proces dydaktyczny z perspektywy uczącego, stąd używa się w nich pojęcia cayynności (takimi czynnościami są np. prezentacja nowego materiału czy też weryfikacja nabytej wiedzy), a nie np. zadania.
} 
opisujący kombinacje i sekwencje czynności standardowej lekcji JO. Zarówno typologia, jak i model czynności zostały wypracowane przy zachowaniu jasno określonych kryteriów statystycznych - musiała na przykład istnieć daleko idąca zgodność (co najmniej 75\%) między osobami wykonującymi transkrypcje lekcji, jeśli chodzi o określenie typów czynności oraz ich ramy czasowe. Dodatkowym elementem instrumentarium badawczego były spotkania z nauczycielami z klas, w których odbywały się nagrania, i analizowanie fragmentów transkrypcji wzbudzających kontrowersje interpretacyjne. W ten sposób zarówno analiza korpusu (a ściślej jego podział na odpowiednie kategorie çynności dydaktycznych), jak i wypracowany w badaniu model uniwersalnej struktury lekcji JO, zyskały w istotny sposób na obiektywności.

Innym przykładem badań jakościowych w nauczaniu/uczeniu się JO w klasie są badania nad komunikacja i strategiami dyskursymnymi (Pekarek 1998). Wpisują się one najczęściej w analizę typu konwersacyjnego, której celem jest zidentyfikowanie i opisanie zachowań adaptacyjnych interlokutorów w komunikacji. Stosowanie technik typowo eksperymentalnych w badaniach nad strategiami komunikacyjnymi jest stosunkowo rzadkie i wymaga od badacza wyjścia poza kontekst klasowego dyskursu i skupienia się na wyselekcjonowanej grupie uczniów/ nauczycieli. W ramach tego typu badań Grassi (2007) opisała strategie nauczycieli w komunikacji z uczniami (pochodzącymi z rodzin emigrantów), których językiem pierwszym nie był język włoski, a którzy znajdowali się w klasach szkolnych razem z rodzimymi użytkownikami języka włoskiego.

\section{Badanie eksploracyjne nad nauczaniem/uczeniem się JO w klasie}

W badaniach nad akwizycją JO kluczowe jest zebranie danych, które od strony treściowej byłyby autentyczne, a od strony technicznej odpowiedniej jakości umożliwiającej analizę $\mathrm{i}$ interpretację. $\mathrm{O}$ ile w badaniach nad akwizycją JO w warunkach naturalnych zebranie danych autentycznych, czyli pochodzacych z codziennej komunikacji między uczącymi się języka docelowego a jego rodzimymi użytkownikami (czyli danymi w naturalnym kontekście) jest bardzo utrudnione, a w praktyce niewykonalne ze względu na bardzo słabą jakość rejestracji (nagrania) takich danych, uniemożliwiającą ich interpretację ${ }^{2}$, o tyle kontekst klasy pozwala na zebranie danych autentycznych i odpowiedniej jakości.

Jeśli chcemy uchwycić dynamikę procesu nauczania/uczenia się JO w klasie i uzyskać dane typowe dla komunikacji w warunkach formalnych, najbardziej adekwatną techniką wydaje się obserwacja i nagranie lekcji JO in vivo. Wybór tychże technik eksploracyjnych nie jest też pozbawiony przeszkód i problemów technicznych. Pierwsza, być może najtrudniejszą przeszkodą, jaką napotka badacz jest znalezienie nauczycieli JO, którzy zgodzą się na nagrywanie ich lekcji, zwłaszcza długich serii znacznie rozciagniętych w czasie. Jest to prawdopodob-

2 Odnośnie zbierania danych w ramach Projektu ESF, por. Perdue (1982). 
nie jedna z przyczyn, dla których badań nad nauczaniem/uczeniem się JO opartych o nagrania in vivo w klasie jest bardzo mało. Jeśli zaś takie badania sa prowadzone, to z reguły mamy do czynienia z krótkimi seriami liczącymi kilka lekcji lub wręcz z pojedynczymi lekcjami, które wykorzystywane są raczej w badaniach eksperymentalnych. I tak np. badanie Pienemanna (1989), z którego zrodziła się ważna dla akwizycjonistów i dydaktyków hipoteza o (nie)nauczalności pewnych struktur JO (ang. processing bypothesis) oparte było na nagraniach kilku lekcji języka niemieckiego jako obcego. Inną istotną trudnością, jakiej przysparza zbieranie danych w klasie JO jest nierówna, często niewystarczająca, jakość nagrań. W naszym badaniu przeprowadzonym w szkołach średnich i dotyczącym nauczania/ uczenia się języka francuskiego jako obcego (Piotrowski 2006a) część danych nie mogła zostać poddana analizie z powodu zbyt słabej jakości nagrań. Huberman i Miles (1991) słusznie zatem podkreślają, że dane jakościowe bardzo często zawierają elementy, które z różnych względów nie nadają się do analizy. W klasie liczącej z reguły kilkunastu uczniów głosy często nakładają się na siebie, w odróżnieniu od wypowiedzi nauczyciela, wypowiedzi uczniów są dużo słabiej artykułowane i nie zawsze są dobrze rejestrowane przez sprzęt nagrywający (w naszym przypadku dyktafon z jednym, centralnie umieszczonym mikrofonem). Można temu problemowi zaradzić wyposażając każdego z uczniów w osobny mikrofon (technika stosowana w badaniach Germaina 1999). Otrzymuje się wtedy dane o nieporównanie lepszej jakości, jednak kosztem spotęgowania paradoksu obserwatora (Labov 1993), czyli, innymi słowy, zwiększając stopień skomplikowania instrumentarium badawczego, otrzymujemy dane o mniejszej autentyczności. Wzmocnienie paradoksu obserwatora jest oczywiście jeszcze wyraźniejsze w przypadku nagrań za pomocą kamery, urządzenia przecież niezbędnego, gdyby chcieć uwzględnić dane parawerbalne, jak gesty czy mimikę interlokutorów. Inna trudność, tym razem podczas wykonywania transkrypcji, polega na przypisaniu poszczególnych wypowiedzi ich właściwym autorom. W dyskursie częściowo odnajdujemy wskazówki pozwalające na identyfikację autorów wypowiedzi (np. kiedy nauczyciel za pomocą imion wywołuje uczniów do odpowiedzi), jednak, naszym zdaniem, niezbędnym uzupełnieniem instrumentarium badawczego są notatki z przebiegu nagrywanej lekcji. Służą one z jednej strony do identyfikacji wypowiedzi, z drugiej pozwalają na odtworzenie pewnych czynności, które umykają podczas nagrania, jak np. notowane słówek/zdań/ struktur języka na tablicy, a są niezbędne do interpretacji wypowiedzi interlokutorów. W notatkach można też uwzględnić, w zależności od celu badania, pewne zachowania interlokutorów (czy np. podczas odgrywania ról uczniowie patrzą na siebie, czy używają notatek, czy wypowiedź nie zamienia się w lekturę) pozwalajace na lepsze uchwycenie dynamiki komunikacji w klasie.

Poniższy fragment naszego korpusu pokazuje, iż właściwe zrozumienie $\mathrm{i}$ interpretacja danych pochodzacych z nagrań in vivo w klasie nie są możliwe bez uwzględnienia związków pomiędzy wypowiedziami ustnymi a wypowiedziami pisemnymi uczestników komunikacji. 
TK1/25.03.97/ $\mathrm{II}^{3}$

E passons maintenant à l'expression de la conséquence nous allons écrire un peu vous écrivez aussi

E notuje na tablicy:

Il est très gentil. Tout le monde l'adore. $=$

Il est si gentil que tout le monde l'adore. $=$

Il est tellement gentil que tout le monde l'adore.

GA czyta rapisane zdania

$\mathrm{E} \quad$ tu peux traduire la deuxième et la troisième phrase?

GA jest tak miły

E oui tak miły

GA że cały świat...

$\mathrm{E} \quad$ non tout le monde

GA < < e wszyscy go uwielbiają

AA <íe wszyscy

GA jest tak samo...?

E tak to jest to samo czyli używamy wymiennie albo 'si' albo 'tellement' czyli wyrażamy $w$ ten sposób konsekwencje czegoś z pewną intensywnoscią tak? jest tak bardzo miły że

$\mathrm{E} \quad$ la tgv va très vite nous serons bientôt arrivés

E (la) tgv c'est quoi? (la) tgv

A? train à grande vitesse

$\mathrm{E} \quad$ oui c'est ça train à grande vitesse

E (la) tgv va très vite nous serons bientôt arrivées Magda

MG le tgviva

Eaaa... (la) tgv?

MG c'est ça

E écoute (la) tgv va très vite

MG tgv va si vite

E oui

MG que

E wkrótce przyjedziemy nous serons bientôt arrivés

E bon viens au tableau et écris cette phrase transformée

$M G$ notuje na tablicy:

Le TGV va si vite que nous serons bientôt arrivés.

E notuje na tablicy:

Il a beaucoup d'argent. Il peut tout acheter. =

Il a tellement d'argent qu'il peut tout acheter. =

Il a tant d'argent qu'il peut tout acheter.

AN czyta zapisane zdania

3 Używane w cytowanym fragmencie korpusu symbole oznaczają: E - nauczyciel, AN, MG, GA - uczniowie, A? - uczeń niezidentyfikowany, AA - grupa kilku uczniów/cała klasa, ? - intonacja wznosząca, $\mathbf{x x x}$ - wypowiedzenia w języku wyjściowym, $x x x$ - komentarze autora badania, $<<$ - wypowiedzenia nakładające się na siebie, xxx... - wypowiedzenie niedokończone, (xxx) - zapis fonetyczny, TK1/25.03.97/II - kod nagranej lekcji. 
Jak badać akwizycję języka obcego w klasie, czyli o zadaniu w perspektywie badań...

E

jak myślicie po co napisaliśmy na tablicy tyle tych zdań chodzi mi o te zdania w tej chwili na tablicy które są żeby sobie uświadomić co? miejsce miejsce tych słówek ,tellement” i ,tant”

Zaznaczenie w transkrypcji zapisanych na tablicy podczas lekcji wyrażeń i struktur w JO nie tylko ułatwia późniejszą interpretację danych, i jest więc cenne z metodologicznego punktu widzenia, ale jest też ważnym źródłem informacji o sposobach podawania (np. wizualizacji) uczącym się elementów języka docelowego.

\section{Zadanie jako jednostka analizy korpusu}

W literaturze z dziedziny akwizycji i dydaktyki JO funkcjonują trzy podstawowe pojęcia służące do określenia wykonywanej na lekcji przez uczących się pracy: czynnność (fr. activité, ang. activity), ćwiczenie (fr. exercice, ang. drill i zadanie (fr. tâche, ang. task). Od czasu pojawienia się Europejskiego systemu opisu kształcenia jezyłkowego (ESOKJ) w roku 2001, to pojęcie radania zajmuje kluczowe miejsce w refleksji poświęconej nauczaniu/uczeniu się języka obcego w środowisku instytucjonalnym. Pojęcie zadania, obecne w dyskursie naukowym od dawna ${ }^{4}$, jest dziś na nowo odkrywane i definiowane w ramach tzw. podejścia akcjonalnego (działaniowego), którego konkretnym pendant jest metodyka zadaniowa (ang. task-based language teaching). W tej perspektywie lekcja JO jawi się jako zbiór określonych zadań zorientowanych na konkretny cel. W założeniu zadania mają mieć wszelkie znamiona autentycznych, czyli bezpośrednio odnosić się do zwykłych codziennych czynności (np. kupowanie czegoś). W tym sensie typowe zadanie byłoby przeciwieństwem klasycznego, czysto formalnego, a więc nieautentycznego ćwiczenia (Rosen 2006).

Praca wykonywana przez uczniów w klasie ma różnorodny charakter, od ćwiczeń polegających na powtarzaniu form po improwizowane odgrywanie ról. Jak więc opisać tak różnorodne czynności i w jakie je ujać ramy? W naszym badaniu, polegającym na obserwacji i opisie lekcji języka obcego w polskiej szkole średniej (por. Piotrowski 2006a), za podstawową jednostkę analizy danych przyjęliśmy zadanie zdefiniowane jako czynność zadana uczniowi (do wykonania), której procedura wykonania została okeréslona w poleceniu. Taka definicja zadania pozwala na opisanie wszelkich czynności wykonywanych w klasie w ramach zajęć dydaktycznych, od bardzo prostych (np. powtarzanie za nauczycielem serii słówek) po stosunkowo skomplikowane (np. opowiedzenie historii z wakacji). W tej perspektywie właściwie wszystkie czynności, z wyjątkiem czynności o charakterze organizacyjnym wykonywanych w J1, traktowane są jak zadania. Zdaniem Gaonac'ha (1990), dla uczącego się JO każde działanie wykonywane w tym języku jest, z psychologicznego punktu widzenia, zadaniem, gdyż wysiłek mentalny przy wykonywaniu czynności w JO jest systematycznie większy niż przy wyko-

4 Odnośnie definicji i typologii zadań w pracach naukowych z dziedziny akwizycji i dydaktyki JO, por. Piotrowski (2006a). 
nywaniu czynności w J1. Z metodologicznego punktu widzenia zadanie może być zatem w pełni operacyjną, jednostką analizy korpusów danych otrzymywanych za pomoca nagrań lekcji in vivo w klasie JO, niezależnie od stosowanego w danym kontekście podejścia. Nie jest zatem istotne, czy w danej klasie stosowana jest metodyka zadaniowa czy też podejście akcjonalne, gdyż każdą lekcję JO da się podzielić na określone zadania. Poniższy fragment korpusu pozwoli zilustrować interesujące nas pojęcie zadania:

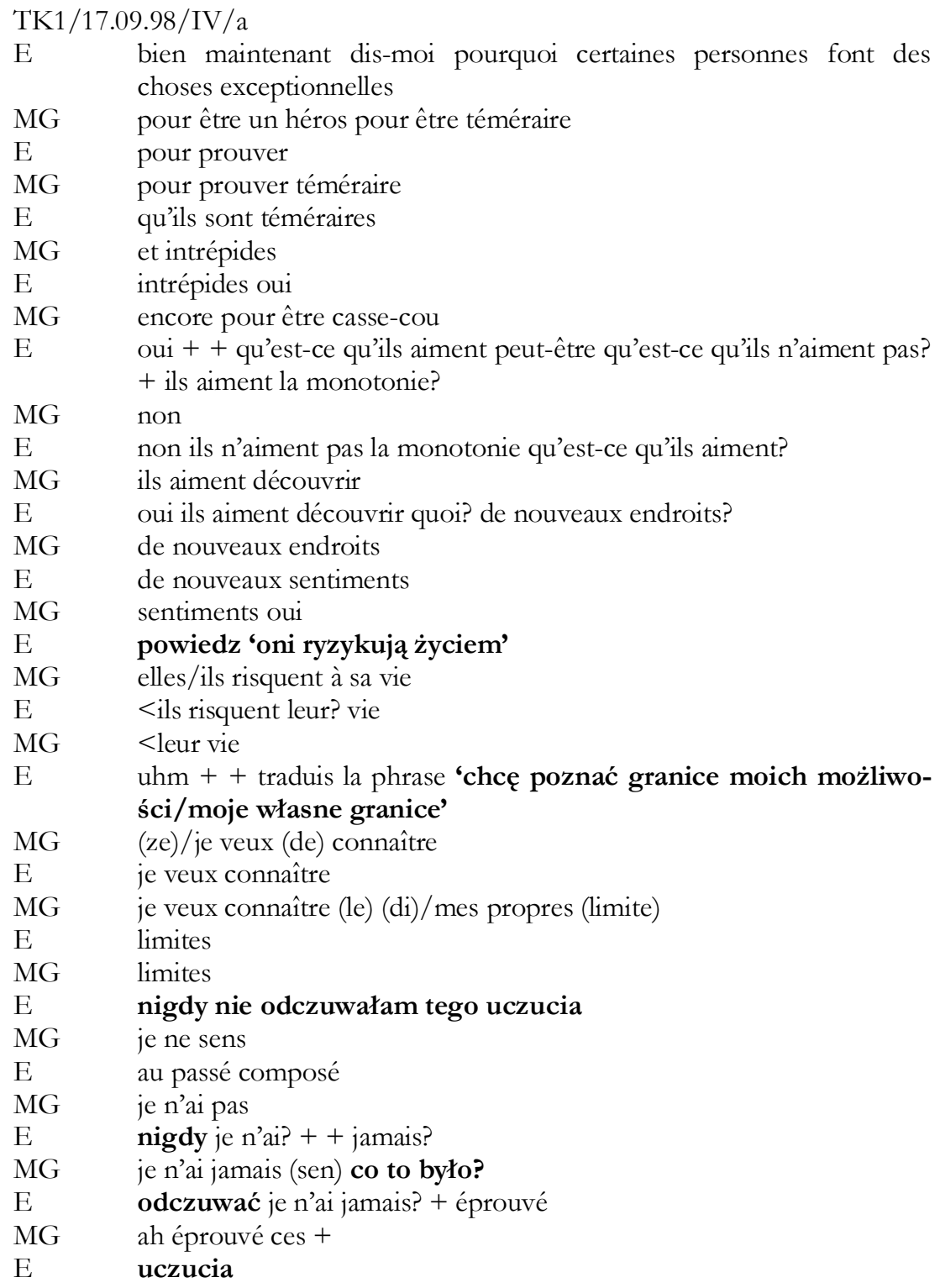


Jak badać akwizycję języka obcego w klasie, czyli o zadaniu w perspektywie badań...

\begin{tabular}{ll}
\hline MG & sentiments \\
E & ces sentiments \\
E & na końcu drogi zobaczyłam + quelque chose \\
MG & à la fin... \\
E & une autre expression \\
MG & au bout \\
E & au bout de? \\
MG & au bout de (zendroi) \\
E & droga + au bout de? \\
MG & chemin \\
E & chemin la route au bout de la route au bout du chemin? \\
MG & je vois \\
E & passé composé \\
MG & j'ai vu \\
E & oui j'ai vu + quelque chose \\
MG & quelque chose \\
E & bon tu conjugues peut-être le verbe 'faire' au présent
\end{tabular}

W powyższym fragmencie można wyróżnić trzy różne zadania wynikające z poleceń adresowanych przez nauczającego (E) do uczącego się (MG): 1) wolna uypowiedź ustna ('pourquoi certaines personnes font des choses exceptionnelles' 'dlaczego niektóre osoby robia nadzwyczajne rzeczy'), 2) ttumaczenie zdań z.J1 na $J O, 3)$ koningacja czasownika 'faire' w czasie teraźniejszym. Sformułowane polecenia pozwalają na określenie typu zadania i umieszczenie go w określonej kategorii. Na przykład według typologii Chaudrona i Valcárcela (1988), opartej o kryterium marginesu swobody przy wykonywaniu zadania, wyróżnione przez nas zadania moga być zakwalifikowane do wolnych, cześsiowo sterowanych i catkowicie sterowanych przez nauczyciela. Warto zauważyć, iż początkowa kwalifikacja zadania na podstawie polecenia może zostać poddana w wattpliwość po przeanalizowaniu rzeczywistej jego realizacji. Dla przykładu, wolna wypowiedź ustna, w której uczeń miał oprzeć się o treść dialogu (jak we fragmencie powyżej), powinna zostać zakwalifikowana do kategorii zadania cześciowo sterowane, jednak przebieg wykonania pokazuje, że mamy do czynienia z zadaniem całkowicie sterowanym, i to zarówno na poziomie treści, jak i formy. Analiza naszego korpusu pokazuje też, że np. zadanie typu odgrywanie ról, które wg Chaudrona i Valcárcela (1988) winno być zakwalifikowane do kategorii zadań wolnych, często $\mathrm{w}$ trakcie realizacji zamienia się w zadanie częściowo albo całkowicie sterowane. W kontekście wykonywania zadań językowych, Breen (1987) słusznie zatem wyróżnia zadania planowane (task-as-workplan) i zadania rzeczywiście realizowane (task-in-process). Zastosowanie innych typologii zadań, opartych o inne kryteria (np. stopień trudności zadania do wykonania), może być pomocne w uchwyceniu innych aspektów akwizycji JO w klasie. W naszym badaniu wypracowanie inwentarza zadań (Piotrowski 2006b) miało istotną wartość heurystyczną (zaobserwowanie i sklasyfikowanie rzeczywiście wykonanych zadań) i stało się punktem wyjścia dla dalszych badań dotyczących komunikacji/dyskursu w klasie JO. 


\section{Wnioski}

Badania jakościowe o charakterze eksploracyjnym, na podstawie korpusu zebranego in vivo w klasie, wydają się potrzebne do uchwycenia dynamiki procesu nauczania/uczenia się JO w warunkach formalnych. Technika polegająca na osobistej obserwacji, nagrywaniu i sporządzaniu notatek pozwala na stosunkowo finezyjną rejestrację tego, co dzieje się podczas lekcji JO w klasie, choć nie jest ona pozbawiona istotnych ograniczeń: w stosunku do badań ilościowych, dane jakościowe cechuje mniejsza obiektywność, stąd utrudnione jest porównywanie wyników różnych badań, niektóre fragmenty komunikacji w klasie umykają rejestracji (np. wypowiedzi słabo artykułowane, niewyraźne), klasa jako grupa uczących się charakteryzuje się też większą niż można a priori przypuszczać zmiennością (np. absencje, zajmowanie miejsc w sali lekcyjnej w zmieniających się często konfiguracjach), którą trudno uchwycić i opisać, a która ma wpływ na komunikację i akwizycję JO.

Pomimo tych obiektywnych trudności techniki eksploracyjne sa, naszym zdaniem, ważnym instrumentem w badaniach nad nauczaniem/uczeniem się JO, gdyż jako jedyne pozwalają na uchwycenie dynamiki komunikacji tak istotnej dla procesu akwizycji w klasie. Analiza korpusu pod kątem wykonywanych zadań pozwala zaś na wgląd w to, co konkretnie robi się w klasie języka obcego, w to jak zadania sa przez uczestników komunikacji postrzegane i rzeczywiście realizowane. Wyniki eksploracyjnych badań nad procesem nauczania/uczenia się JO w klasie mogą też być realnym punktem odniesienia dla ewentualnych propozycji dydaktycznych wysuwanych zbyt często jeszcze w sposób intuicyjny.

\section{BIBLIOGRAFIA}

Allwright, R. L. 1983. „Classroom-centered research on language teaching and learning: A brief historical overview". TESOL Quarterly 17. 191-204.

Chaudron, C. 1986. „The interaction of quantitative and qualitative approaches to research: A view of the second language classroom". TESOL Quarterly 20. 709-717.

Chaudron, C. i Valcárcel, M. 1988. A process-product study of communicative language teaching (Final report submitted to the Comite Conjunto Hispano-Norteamericano para la Cooperación Cultural y Educativa, Madrid). Murcia, Espagne: Universidad de Murcia, Escuela Universitaria de Magisterio.

Cook, T. D. i Reichardt, C. S. (red.). 1979. Qualitative and quantitative methods in evaluation research. Beverly Hills, CA: Sage.

Dausendschőn-Gay, U., Gúlich, E. i Kraft, E. (red.). 1991. Linguistische Interaktionsanalysen. Túbingen: Niemeyer.

Doughty, C. J. i Pica, T. 1985. „Input and interaction in the communicative language classroom: A comparison of teacher-fronted and group activities", w: Gass, S. i Madden, C. (red.). 1985. 115-135. 
Doughty, C. J. i Pica, T. 1986. „Information-gap tasks: Do they facilitate second language acquisition?”. TESOL Quarterly 20. 305-325.

Ellis, R. 1990. Instructed second language acquisition. Oxford. Blackwell.

Fotos, S. i Ellis, R. 1991. „Communicating about grammar: A task-based approach”. TESOL Quarterly 25. 605-628.

Gaonac'h, D. (red.). 1990. Acquisition et utilisation d'une langue étrangère. L'approche cognitive. Paris: Hachette.

Gass, S. i Madden, C. (red.). 1985. Input in second language acquisition. Rowely, MA, Newbury House.

Germain, C. 1999. „Structure fondamentale de l'enseignement d'une langue étrangère ou seconde". Etudes de linguistique appliquée 114. 171-187.

Grassi, R. 2007. Parlare all'allievo straniero. Strategie di adattamento linguistico nella classe plurilingue. Perugia: Guerra Edizioni.

Gülich, E. 1991. „Pour une ethnométhodologie linguistique: description de séquences conversationnelles explicatives”, w: Dausendschőn-Gay, U., Gülich, E. i Kraft, E. (red.). 1991. 325-364.

Huberman, A. M. i Miles, M. B. 1991. Analyse des données qualitatives. Bruxelles: De Boeck (tłum. De Backer, C. i Lamongie, V.).

Hymes, D. (red.). 1966. Language in culture and society. A reader in linguistics and anthropology. New-York: Harper \& Row.

Klein, W. i Perdue, C. 1997. „The basic variety (or: Couldn't natural languages be much simpler?)". Second Language Research 13. 301-348.

Krieger-Knieja, J. i Paprocka-Piotrowska, U. (red.). 2006. Komunikacja jezykowa w spoleczeństwie komunikacyjnym. Nowe wyzwania dla dydaketyki jezyków obcych. Lublin: Towarzystwo Naukowe KUL.

Labov, W. 1993. Le parler ordinaire. Paris: Les Editions de Minuit. (tłum. Kihm, A.).

Larsen-Freeman, D. i Long, M. H. 1991. An introduction to second language acquisition research. London: Longman.

Nunan, D. 1991. „Communicative tasks and the language curriculum”. TESOL Quarterly 25. 279-295.

Pekarek, S. 1998. „Ritualisation du discours et conditions d'acquisition en classe de L2", w: Souchon, M. (red.). 1998. 79-89.

Perdue, C. (red.). 1982. Second language acquisition by adult immigrants. A field manual. Strasbourg: European Science Foundation.

Piotrowski, S. 2006a. Gestion des tâches et mode d'accès à la langue. L'apprentissage du français en milieu institutionnel polonais. Lublin: Towarzystwo Naukowe KUL.

Piotrowski, S. 2006b „Uniformizacja zadań językowych w klasie języka drugiego”, w: Krieger-Knieja, J. i Paprocka-Piotrowska, U. (red.). 2006. 194-201.

Pienemann, M. 1989. „Is language teachable? Psycholinguistic experiments and hypotheses". Applied Linguistics 10. 52-79.

Reichardt, C. S. i Cook, T. D. 1979. „Beyond qualitative versus quantitative methods", w: Cook, T. D. i Reichardt, C. S. (red.). 1979. 7-32. 
Rosen, E. 2006. Le point sur le Cadre européen commun de référence pour les langues. Paris: CLE International.

Souchon, M. (red.). 1998. Pratiques discursives et acquisition des langues étrangères. Actes du Xème colloque international „Acquisition d'une langue étrangère: perspectives et recherches". Besançon, Université de Franche-Comté: Centre de linguistique appliquée. 